Stars and Strife 
Also by John Redwood

CONTROLLING PUBLIC INDUSTRIES (with John Match)

GOING FOR BROKE

OUR CURRENCY, OUR COUNTRY

POPULAR CAPITALISM

PUBLIC ENTERPRISE IN CRISIS

REASON, RIDICULE AND RELIGION

THE DEATH OF BRITAIN? The UK's Constitutional Crisis

THE GLOBAL MARKETPLACE 


\section{Stars and Strife}

The Coming Conflicts

between the USA and

the European Union

John Redwood 


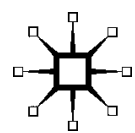

(c) John Redwood 2001

All rights reserved. No reproduction, copy or transmission of this publication may be made without written permission.

No paragraph of this publication may be reproduced, copied or transmitted save with written permission or in accordance with the provisions of the Copyright, Designs and Patents Act 1988, or under the terms of any licence permitting limited copying issued by the Copyright Licensing Agency, 90 Tottenham Court Road, London W1P OLP.

Any person who does any unauthorised act in relation to this publication may be liable to criminal prosecution and civil claims for damages.

The author has asserted his right to be identified as the author of this work in accordance with the Copyright, Designs and Patents Act 1988.

First published 2001 by

PALGRAVE

Houndmills, Basingstoke, Hampshire RG21 6XS and 175 Fifth Avenue, New York, N. Y. 10010

Companies and representatives throughout the world

PALGRAVE is the new global academic imprint of St. Martin's Press LLC Scholarly and Reference Division and Palgrave Publishers Ltd (formerly Macmillan Press Ltd).

\section{ISBN 978-0-333-91841-8 ISBN 978-0-333-98558-8 (eBook)} DOI $10.1057 / 9780333985588$

This book is printed on paper suitable for recycling and made from fully managed and sustained forest sources.

A catalogue record for this book is available from the British Library.

Library of Congress Cataloging-in-Publication Data Redwood, John.

Stars \& strife : the coming conflicts between the USA and the European Union / John Redwood.

p. $\mathrm{cm}$.

Includes bibliographical references and index.

1. European Union-United States. 2. International economic integration. I. Title: Stars and strife. II. Title.

KJE5112.U6 R44 2001

341.242'2'0973-dc21

00-069868

$\begin{array}{rrrrrrrrrr}10 & 9 & 8 & 7 & 6 & 5 & 4 & 3 & 2 & 1 \\ 10 & 09 & 08 & 07 & 06 & 05 & 04 & 03 & 02 & 01\end{array}$




\section{Contents}

Preface

Introduction

1. Britain and Britishness at the Crossroads

2. A United States of Europe or a Union of English-Speaking Peoples: Two Rival Models for the US and Britain

3. The US, the UK and the UN: The Special Relationship Policing the World

4. Free Trade and Democracy: The Ideals of the Wider English-Speaking Commonwealth

5. Doing Business the US Way: Is the UK Growing More Like the US Day by Day?

6. The United States of America and the United States of Europe

7. What's in an English-Speaking Union for the US?

8. What Kind of Renegotiation with the EU does Britain Want?

9. Conclusions

Notes

Bibliography

Index 


\section{Preface}

It took me a little while to understand just what modernisation meant to the new Labour government that swept to power in Britain in 1997. It took me an equally long time to think through how the AngloAmerican relationship was being subtly but dramatically changed by the Clinton-Blair axis as the twentieth century drew to a close. I started to write my book The Death of Britain? setting out the whole array of constitutional and cultural changes that the British government was trying to bring about, to get the UK to fit in more easily and comfortably with the European Union plan.

After it was published, I discovered I was not alone in fearing for the future of the Mother of Parliaments and the style of combative democracy and national unity that had been pioneered in the British islands offshore from Western Europe. I had worried in case my book and its title were too sensational. When I started writing, few thought the very future of our democracy as we know it was in question. By the time I had finished writing, others were coming to the same conclusion.

Shortly after The Death of Britain? Peter Hitchens produced his excellent The Abolition of Britain (1999) which tackled the same subject and idea from a different vantage point, placing more emphasis on the educational and cultural changes of some thirty years and rather less on the constitutional changes now underway. Simon Heffer wrote his elegant and distinctive Nor Shall my Sword (1999), and Andrew Marr, from a centre-left viewpoint, weighed in with The Day Britain Died (2000). All of us agreed from our different starting points that the new pressures on Britain are great and could succeed in breaking the country apart.

Many people read one or more of these books, and joined the debate which was underway in the media and the newspapers. Soon it became very apparent that the warnings were well heeded, but people felt the need for something more positive. They kept asking me, 'What is the alternative? What can we do to prevent this chain of events which we, too, fear will happen?' 'Is there any way', they 
asked, 'that we can be modern and be part of global economic success? What is the alternative to the European destiny which many leaders implicitly accept but fear to voice openly?'

I decided it was time to set out at greater length an idea that I had started off in 1995 when visiting Washington. If freer trade and a common market made sense for the Europeans in Western Europe, and separately made sense for North Americans through NAFTA (the North American Free Trade Agreement), why couldn't Britain bring the two together, or enjoy both? It led me to ask why some US policymakers thought the creation of a United Europe to be a good idea, when it was likely to be unfriendly to the US, and to create disputes and troubles in trade, foreign policy, environmental policy and defence.

The Conservative government in Britain in 1996 adopted the policy of widening free trade by negotiation between the EU and NAFTA. It was left ambiguous as to whether Britain itself would seek to join if the EU, as a whole, would not. This policy was sharpened and renewed in Opposition in 1998. Republicans in the US have also proposed this, from Speaker Gingrich through to Senator Gramm. It is an idea whose time is coming.

This book is intended to remind the British people that we are part of a huge English-speaking community through the Commonwealth and the special relationship with the US. It alerts US policy-makers to the importance of the changes underway as Europe presses towards Union. It seeks that understanding and common working across the Atlantic between the old English-speaking world and the new, in the belief that democracy, free trade and liberty are the best ways forward for both of us. It warns that the emerging super-state, the United States of Europe, does not share these Anglo-Saxon values. 